\title{
KULTURNA GEOGRAFIJA. RAZNOLIKOST SVETOVNEGA PREBIVALSTVA IN KULTURNIH POKRAJIN
}

Jernej Zupančič: Kulturna geografija. Raznolikost svetovnega prebivalstva in kulturnih pokrajin. Znanstvena založba Filozofske fakutete, 26I str. Ljubljana, 2013

Kulturna geografija je geografska veja, ki obravnava pokrajino kot rezultat součinkovanja naravnih razmer ter materialne in duhovne kulture - človeka. Zato posebno

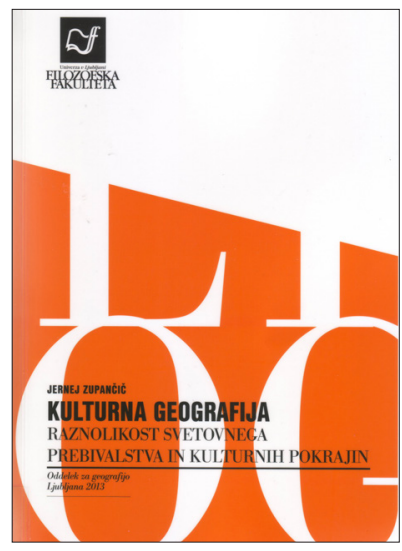
pozornost posveča geografskim vidikom razvoja prebivalstva in njegovim značilnostim ter kulturni pokrajini, ki se je izoblikovala kot rezultat delovanja človeške družbe v različnih naravnih okoljih. Pojem kulturna geografija v slovenski geografiji ni udomačen, pogosto se jo celo zamenjuje z družbeno geografijo, ki pa je, glede na predmet preučevanja, zasnovana širše od kulturne geografije.

Jernej Zupančič z visokošolskim učbenikom Kulturna geografija. Raznolikost svetovnega prebivalstva in kulturnih pokrajin prvič v slovenski geografiji opredeljuje to vejo družbene geografije s tem imenom in vsebino. $\mathrm{V}$ učbeniku na sistematičen način obravnava temeljne pojme in vsebino kulturne geografije. Študentom geografije in tudi drugim bralcem poskuša olajšati razumevanje pojma kulturna geografija, hkrati pa z obsežnim kartografskim gradivom ter s številnimi primeri iz literature predstavlja temeljna področja preučevanja kulturne geografije, čemur sledijo tudi posamezna poglavja.

$\mathrm{V}$ uvodnem poglavju avtor spregovori o pojavu in pojmu kulturne geografije. V nadaljevanju prikaže geografsko razsežnost pojava človeka $\mathrm{v}$ tesni navezavi z razvojem kulturne pokrajine. Sledi logično nadaljevanje, to je geografska analiza civilizacij: njihovega razvoja, prilagajanja narave svojim potrebam ter njihova hegemonija. V nadaljevanju visokošolskega učbenika so obsežna poglavja namenjena analizi in geografskemu vrednotenju posameznih družbenih pojavov: religije, jezikovnih skupin, etničnih pojavov, države kot geografskega pojava ter družbenih razredov. V prilogi na koncu učbenika je priložen krajši podatkovnik o najpomembnejših strukturnih značilnostih družbenih skupin in skupnosti.

Rdeča nit vseh poglavij je nadgradnja klasičnih geografskih pristopov k preučevanju kulture s problemskim pristopom. Avtor med besedilom pogosto posega po izpostavljanju aktualnih nasprotij, odgovarja na ključna vprašanja razvoja družbe in njenega vpliva na razvoj pokrajine ter predvsem $\mathrm{k}$ njeni geografski dimenziji. Kritičen pogled na obravnavano tematiko omogoča študentom boljše razumevanje sveta in aktualnih dogodkov. Zahtevne teorije in strokovna terminologija so ponazorjeni s številnimi primeri, ki kažejo na prostorski obseg in kompleksnost delovanja družbe ter njenih interakcij z naravo. Sprotno 
navajanje uporabljenih virov in literature omogoča študirajočemu nadaljnji poglobljen študij izbranih vsebin. Posebna odlika učbenika je povezovanje dognanj kulturne geografije z drugimi podpodročji družbene geografije, posebno politične geografije in delno tudi ekonomske geografije.

Simon Kušar 